\begin{tabular}{llllll|llllllll|lllll} 
H A R V A R D & B U S I N E S S & S C H & O & 0 & L
\end{tabular}

\title{
BUSINESS
}
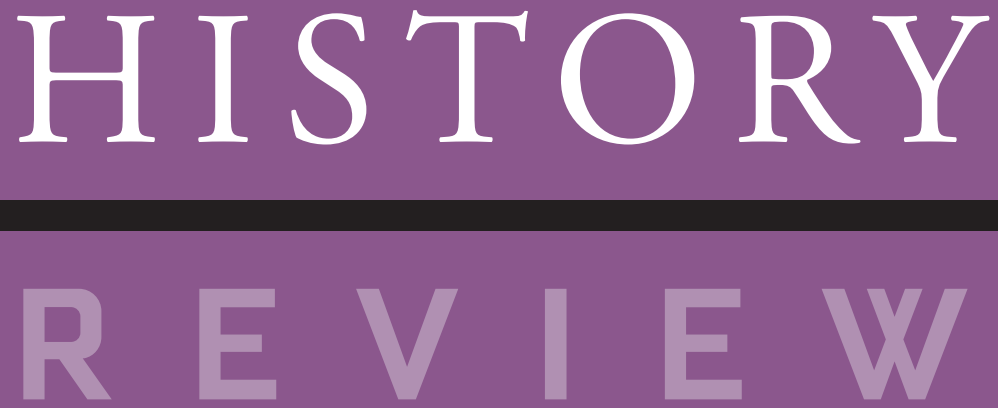
(C) 2019 by The President and Fellows of Harvard College. All rights reserved.

ISSN 0007-6805 


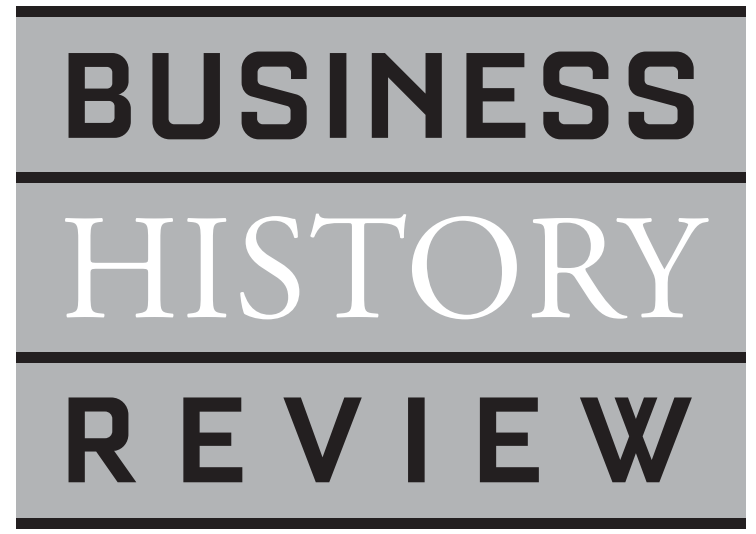

VOLUME 93 NUMBER 3 A UTUMN 20019

Editors $\bullet$ Walter A. Friedman and Geoffrey Jones

Editorial Coordinator $\bullet$ Kristine Haglund

Production Coordinator • Linda Cornell

Harvard University

\section{EDITORIAL ADVISORY BOARD}

Franco Amatori, Università Bocconi

Edward J. Balleisen, Duke University

María Inés Barbero, Universidad de Buenos Aires

Bernardo Bátiz-Lazo, Bangor University

Hartmut Berghoff, Göttingen University

Ann-Kristin Bergquist, Umeå University

Marcelo Bucheli, University of Illinois

Brian R. Cheffins, University of Cambridge

Andrea Colli, Bocconi University

Carlos Dávila, Universidad de los Andes

Jeffrey Fear, University of Glasgow

Patrick Fridenson, École des Hautes Études

Margaret B. W. Graham, McGill University

Per H. Hansen, Copenhagen Business School
Gelina Harlaftis, Ionian University

Richard R. John, Columbia University Pamela W. Laird, University of Colorado, Denver Kenneth J. Lipartito, Florida International University

Rowena Olegario, University of Oxford

Susie J. Pak, St. John's University

Nuria Puig, Universidad Complutense de Madrid

Mary B. Rose, Lancaster University

Catherine Schenk, University of Oxford

Keetie Sluyterman, Utrecht University

Simon Ville, University of Wollongong

Mira Wilkins, Florida International University

Martín Monsalve Zanatti, Universidad del Pacífico

Jonathan Zeitlin, University of Amsterdam

BOOK REVIEW BOARD

Xavier Durán, Universidad de los Andes

Valeria Giacomin, University of Southern California

Ai Hisano, Kyoto University

Caitlin C. Rosenthal, University of California, Berkeley

Chinmay Tumbe, Indian Institute of Management Ahmedabad

H A R V A R D 
Business History Review is a top-tier refereed journal that seeks to publish articles with rigorous primary research that address major topics of debate, offer comparative perspectives, and contribute to the broadening of the subject. We are primarily concerned with the history of entrepreneurs, firms, and business systems, and with the subjects of innovation, globalization, and regulation. We are also interested in the relation of businesses to the environment and to political regimes.

The Business History Review (ISSN 0007-6805) is published 4 times a year, in the spring, summer, autumn, and winter by Cambridge University Press, One Liberty Plaza, 20th Floor, New York, NY 10006, for Harvard Business School.

- EDITORIAL OFFICE Business History Review, Harvard Business School, Soldiers Field, Boston, MA 02163, USA, Telephone: +1 617495 1003, Fax: +1 617495 2705, E-mail: bhr@hbs.edu.

- SUBMISSIONS See Guidelines for Contributors on inside back cover. Manuscripts, books for review, commentary, and all editorial correspondence should be sent to Walter A. Friedman, Coeditor (contact details as above).

- PUBLISHING OFFICE Cambridge University Press, UPH, Shaftesbury Road, Cambridge CB2 8BS, UK. - SUBSCRIPTIONS The 2019 subscription price is US\$334 (£210) for institutions' print and electronic access. The paper-only price for individuals is US\$70 ( $£ 50)$. There is a reduced rate of US\$40 (£25) for students, Harvard Business School alumni, and members of the following associations: Academy of Management, Association of Business Historians, Business History Conference, Business History Society of Japan, Economic History Association, European Business History Association, German Association for Business Historians.

All prices include delivery by air if appropriate, and exclude VAT. EU subscribers (outside the UK) who are not registered for VAT should add VAT at their country's rate. VAT-registered members should provide their VAT registration number. Japanese prices for institutions (including ASP delivery) are available from Kinokuniya Company Ltd., P.O. Box 55, Chitose, Tokyo 156, Japan.

Orders, which must be accompanied by payment, may be sent to a bookseller, subscription agent, or direct to the publisher: Cambridge University Press, UPH, Shaftesbury Road, Cambridge CB2 8BS, UK; or in the USA, Canada, and Mexico: Cambridge University Press, Journals Fulfillment Department, One Liberty Plaza, 20th floor, New York, NY 10006.

Periodicals postage is paid at New York, NY and additional mailing offices. POSTMASTER: send address changes in USA, Canada, and Mexico to Journals Fulfillment Department, One Liberty Plaza, 20th floor, New York, NY 10006; or e-mail subscriptions_newyork@cambridge.org. Send address changes elsewhere to Cambridge University Press, UPH, Shaftesbury Road, Cambridge, CB2 8BS, UK.

- RIGHTS AND PERMISSIONS Please contact Linda Nicol, Cambridge University Press, UPH, Shaftesbury Road, Cambridge, CB2 8BS, UK.

- COPYING This journal is registered with the Copyright Clearance Center, 222 Rosewood Drive, Danvers, MA 01923, USA. Organizations in the USA who are also registered with the C.C.C. may therefore copy material (beyond the limits permitted by sections 107 and 108 of US Copyright law) subject to payment to the C.C.C. of the per-copy fee of US\$15.0o. This consent does not extend to a multiple copying for promotional or commercial purposes. Code 0007-6805/17. ISI Tear Sheet Service, 3501 Market Street, Philadelphia, PA 19104, USA, is authorized to supply single copies of separate articles for private use only. Organizations authorized by the Copyright Licensing Agency may also copy material subject to the usual conditions. For all other use, permission should be sought from Cambridge or from the American branch of Cambridge University Press.

- ADVERTISING To advertise in the journal please contact the relevant advertising promoter for your area: in the USA, Canada, or Mexico: USASales@cambridge.org or telephone +1 212337 5053; in the UK, Europe, or rest of the world: ad_sales@cambridge.org or telephone +44 1223325083 .

- Business History Review articles are listed in ABI/INFORM Global, America: History and Life, Book Review Index, Business Methods Index, Business Periodical Index, EBSCO Academic Search Premiere, EBSCO Business Source Complete, Historical Abstracts, IBSS, Journal of Economic Literature, Journal Citation Reports/Social Sciences Edition, JSTOR, Proquest 50oo, Proquest Central, Social Sciences Citation Index ${ }^{\circledR}$, Social Scisearch ${ }^{\circledR}$, and Standard Periodical Directory.

- The paper used in this journal meets the minimum requirements of the American National Standard for Permanence of Paper for Printed Library Materials, Z.39.48 and is 50\% recycled, 10\% postconsumer.

- Visit our Web site for further details and current information: https://www.cambridge.org/core/journals/ business-history-review. 


\title{
Contents
}

\section{ENTREPRENEURSHIP AND PHILANTHROPY}

Editors' Note • 441

\section{INTRODUCTION}

Charles Harvey, Mairi Maclean, and Roy Suddaby, Historical

Perspectives on Entrepreneurship and Philanthropy • 443

\section{ARTICLES}

Catherine Casson and Mark Casson, "To Dispose of Wealth in Works of Charity": Entrepreneurship and Philanthropy in Medieval England • 473

Alice Shepherd and Steven Toms, Entrepreneurship, Strategy, and Business Philanthropy: Cotton Textiles in the British Industrial Revolution $\cdot 503$

Niall G. MacKenzie, Jillian Gordon, and Martin J. Gannon, A Spirit of Generosity: Philanthropy in the Scotch Whisky Industry • 529

Nicolas J. Duquette, Founders' Fortunes and Philanthropy: A History of the U.S. Charitable-Contribution Deduction • 553

\section{ANNOUNCEMENTS • 585}

\author{
RESEARCH NOTE \\ Sudev Sheth, Unconventional Histories of Capitalism $• 589$
}

\section{REVIEW ESSAY}

Mira Wilkins, A review of Asli M. Colpan and Takashi Hikino, editors, Business Groups in the West: Origins, Evolution, and Resilience • 599 


\section{BOOK REVIEWS}

Michael R. Adamson, Oil and Urbanization on the Pacific Coast:

Ralph Bramel Lloyd and the Shaping of the Urban West. Reviewed by Stanley Buder • 642

Anthony B. Atkinson, Measuring Poverty around the World. Reviewed by Malcolm Sawyer • 627

Naomi Beck, Hayek and the Evolution of Capitalism. Reviewed by Janek Wasserman • 611

Youssef Cassis and Giuseppe Telesca, editors, Financial Elites and European Banking: Historical Perspectives. Reviewed by Eric Godelier • 619

Amanda Ciafone, Counter-Cola: A Multinational History of the Global Corporation. Reviewed by Bart Elmore • 630

James W. Cortada, IBM: The Rise and Fall and Reinvention of a Global Icon. Reviewed by David Stebenne • 632

Nan Enstad, Cigarettes, Inc.: An Intimate History of Corporate Imperialism. Reviewed by Barbara Hahn • 635

Philip T. Hoffman, Gilles Postel-Vinay, and Jean-Laurent Rosenthal, Dark Matter Credit: The Development of Peer-to-Peer Lending and Banking in France. Reviewed by Guillaume Bazot • 622

Louis Hyman, Temp: How American Work, American Business, and the American Dream Became Temporary. Reviewed by Kira Lussier • 639

David K. Johnson, Buying Gay: How Physique Entrepreneurs Sparked a Movement. Reviewed by Marc J. Stern • 647

Lisa Rofel and Sylvia J. Yanagisako, Fabricating Transnational Capitalism: A Collaborative Ethnography of Italian-Chinese Global Fashion. Reviewed by Véronique Pouillard • 650

Quinn Slobodian, Globalists: The End of Empire and the Birth of Neoliberalism. Reviewed by Sophus A. Reinert • 613

Joe William Trotter Jr., Workers on Arrival: Black Labor in the Making of America. Reviewed by Eric Arnesen • 637

Michael Vatikiotis, Blood and Silk: Power and Conflict in Modern Southeast Asia. Reviewed by Valeria Giacomin • 653 
Erika Vause, In the Red and in the Black: Debt, Dishonor, and the Law in France between the Revolutions. Reviewed by Francesca Trivellato $\bullet 625$

Elizabeth Zanoni, Migrant Marketplaces: Food and Italians in North and South America. Reviewed by Santiago Pérez • 645 